\title{
ISOLATION OF EISENINE FROM A BROWN ALGA, ECKLONIA CAVA
}

\author{
Shiro KONAGAYA* \\ (Received July 27, 1966)
}

The ocourrence of low molecular weight peptides in certain algae was often reported by many workers ${ }^{1-5)}$ and three chemically distinct peptides have hitherto been obtained in crystalline form. OHIRA ${ }^{61}$ isolated a tripeptide, eisenine, from a brown alga, Eisenia bicyclis, and proposed the structure, L-Pyrglu-L-Glu $\left(\mathrm{NH}_{2}\right)$-L-Ala. Recently this structure was synthetically determined by SHIBA et al.7,8). DECKER et al. ${ }^{9)}$ also obtained a tripeptide named fastigiatine ${ }^{10)}$ from a brown alga, Pelvetia fastigiata, and suggested its structure to be L-Pyrglu-L-Glu $\left(\mathrm{NH}_{2}\right)-\mathrm{L}-\mathrm{Glu}\left(\mathrm{NH}_{2}\right)$. The last is arginylglutamine which was isolated from a green alga, Cladophora sp., by MAKISUM1 ${ }^{11)}$.

OGINO $^{5)}$ found the presence of a peptide in an alcoholic extract of a brown alga, Ecklonia cava, and suggested that the peptide may be eisenine in view of the taxonomic relation between Eisenia and Ecklonia, but he did not show any experimental evidence.

In the present paper, the isolation of eisnine from Ecklonia cava and identification as such are described.

\section{Experimental and Results}

Material Laminae of Ecklonia cava were collected from the sea off Kominato area in Chiba Prefecture in the early fall, stored at $-20^{\circ} \mathrm{C}$ and used in this investigation.

Isolation of eisenine The frozen laminae $(2 \mathrm{~kg})$ were mechanically ground into fine pieces with $2 l$ of $80 \%$ ethanol and then subjected to extraction for $3 \mathrm{hr}$, at about $80^{\circ} \mathrm{C}$ with occasional swirling. The extract was filtered through gauze. A second extraction was made under the same conditions. The combined extracts were kept overnight in a refrigerator and the gummy materials which appeared were removed by centrifugation. The supernatant was concentrated to about $500 \mathrm{ml}$ under reduced pressure at $40^{\circ} \mathrm{C}$. The resultant solution was treated with $7 l$ of saturated basic lead acetate solution, and the filtrate, being freed from the excess lead lead with $\mathrm{H}_{2} \mathrm{~S}$, was concentrated under reduced pressure. The peptide was then precipitated by mercuric acetate in a similar manner as described by OHIRA ${ }^{6)}$. The mercuric salt of peptide,

Abbreviations: Pyrglu, pyroglutamic acid (pyrolidoncarboxylic acid); FDNB, 1-fluoro-2,4. dinitrobenzene; DNP-, 2,4-dinitrophenyl.

* Tokyo University of Fisheries, Minato-ku, Tokyo, Japan (小與谷串郎. 東京水産大学). 
being washed with cold $50 \%$ ethanol, was decomposed by the usual manner with $\mathrm{H}_{2} \mathrm{~S}$. Formed $\mathrm{HgS}$ was filtered off and the filtrate was evaporated to a syrupy liquid and diluted with $5 \mathrm{~m} l$ of water. To this solution was added $75 \mathrm{ml}$ of ethanol, and the mixture was kept at $-20^{\circ} \mathrm{C}$ for three days. The precipitates were collected by filtration and recrystallized from water-ethanol (1:15), the yield was $860 \mathrm{mg}$. For further purification, the product was dissolved in $10 \mathrm{~m} l$ of water and passed through a column $(4 \times$ $25 \mathrm{~cm}$ ) of Dowex $50 \times 2$ in hydrogen form. The column was washed with $500 \mathrm{~m} l$ of water, and the eluate was evaporated at $45^{\circ} \mathrm{C}$ under reduced pressure to yield a solid residue which was readily crystallized from water-ethanol $(1: 15)$ in long needles*: $\mathrm{m} . \mathrm{p}$. $223 \sim 224^{\circ} \mathrm{C}$ (decomp. in a sealed capilary tube), $[\alpha]_{589}^{22}=-50.3^{\circ}(c=1.10$ in water). Anal. Found: $\mathrm{C}, 47.71 ; \mathrm{H}, 6.49 ; \mathrm{N}, 16.33$; eq. wt., $* * 342$. Calcd. for $\mathrm{C}_{13} \mathrm{H}_{20} \mathrm{O}_{6} \mathrm{~N}_{4}: \mathrm{C}$, $47.56 ; \mathrm{H}, 6.16 ; \mathrm{N}, 17.08$; eq. wt. 328 . The aqueous solution of substance was acidic and positive to the biuret test but negative to the ninhydrin test.

Amino acid analysis The peptide $(21.17 \mathrm{mg})$ was hydrolyzed with $2.5 \mathrm{ml}$ of twice glass-distilled $6 \mathrm{~N} \mathrm{HCl}$ in a sealed tube at $110^{\circ} \mathrm{C}$ for $24 \mathrm{hr}$. The constituent amino acids were estimated by the use of Hitachi amino acid analyser.

Table 1. Stoichiometry of constituents in the peptide.

\begin{tabular}{c|c|c|c}
\multirow{2}{*}{ Peptide } & \multicolumn{3}{|c}{ Constituent } \\
\hline $0.616 \mu \mathrm{M}^{*}$ & Ala & $\mathrm{Glu}$ & $\mathrm{NH}_{\mathbf{3}}$ \\
\hline $0.573 \mu \mathrm{M}$ & $1.20 \mu \mathrm{M}$ & $0.585 \mu \mathrm{M}$ \\
\hline
\end{tabular}

* Calculated on the basis of a molecular weight of 328 .

The results shown in Table 1 indicate that the peptide consists of an alanine residue and two glutamic acid residues, one of which must exist as amide.

End-group analysis The $\mathrm{N}$-terminal analysis of the peptide gave a negative result by the ordinary FDNB method ${ }^{12,13)}$. The $\mathrm{C}$-terminal amino acid was characterized by hydrazinolysis ${ }^{14,15}$. About $5 \mathrm{mg}$ of the peptide was hydrazinolyzed with $0.5 \mathrm{ml}$ of anhydrous hydrazine in a sealed tube at $100^{\circ} \mathrm{C}$ for $6 \mathrm{hr}$., and the evaporated hydrazinolyzate was analyzed by one dimensional paper chromatography using two different solvent systems, phenol-water (1:4) and pyridine-aniline-water $(9: 1: 4)^{14}$. The C-terminal amino acid residue of the peptide was shown to be alanine.

Pronase digestion The pepticle $(7.3 \mathrm{mg})$ was dissolved in $2.5 \mathrm{~m} l$ of $0.02 \mathrm{M}$ sodium phosphate buffer ( $\mathrm{pH} 8.0$ ) and mixed with an equal volume of a freshly prepared solution of Pronase $\mathrm{P}$, Streptomyses griseus protease, in the same buffer $(0.2$ $\mathrm{mg}$ per $\mathrm{m} b$. The mixture was maintained at $30^{\circ} \mathrm{C}$ with gentle shaking for $24 \mathrm{hr}$. The enzymatic hydrolyzate was dialyzed against about $8 \mathrm{ml}$ of water at $5^{\circ} \mathrm{C}$ for two

* Prior to analyses, the material was dried at $110^{\circ} \mathrm{C}$ over $\mathrm{P}_{2} \mathrm{O}_{5}$ in vacuum for $15 \mathrm{hr}$.

** Ten milligrams of sample was dissolved in $3 \mathrm{ml}$ of $60 \%$ ethanol and titrared with $0.02 \mathrm{~N}$ $\mathrm{NaOH}$ solution. 
days with two changes per day and the combined dialyzates were liophilized. The residue was dissolved in a small amount of water and subjected to two dimensional paper chromatography using butanol-acetic acid-water (4:1:2) and phenol-water (4:1) for the first and second development, respectively.

Strong alanine and weak glutamine spots were revealed on the paper by ninhydrin. Furthermore chlorine-starch-iodide ${ }^{16}$ ) revealed three additional spots, two of which were quite faint and corresponded to pyroglutamic acid and intact peptide, respectively, while the other strong spot seemed to be a dipeptide produced from the original peptide by the action of Pronase.

With respect to the specificity of Pronase ${ }^{17)}$, these facts indicate that the original peptide has no peptide bond involving the $\gamma$-carboxyl group of glutamic acid, and also suggest that the peptide possesses a sequence of Pyrglu-Glu $\left(\mathrm{NH}_{2}\right)$-Ala.

Reduction with sodium in ethanol In order to ascertain the occurrence of pyroglutamic acid residue at the terminal positon, the peptide $(20 \mathrm{mg}$ ) was reduced with sodium in ethanol by FisCHER's method modified by OHIRA ${ }^{19)}$. The reduction was followed by usual dinitrophenylation ${ }^{12,13}$ ). In the ethyl acetate-soluble fraction, small amounts of DNP-proline, DNP-alanine, DNP-glutamic acid but no trace of DNPglutamine were detected by one dimensional paper chromatography using $1.5 \mathrm{M}$ phosphate buffer ( $\mathrm{pH} 6$ ) and tert-amyl alcohol-phthalate buffer (pH 5) as solvents ${ }^{13}$. The acidic aqueous phase left after extraction with ethyl acetate was subjected to a column $(2 \times 5 \mathrm{~cm})$ of talc ${ }^{20}$ and developed with $N \mathrm{HCl}$-ethanol (1:4). A sharp yellow band was obtained. The effluent containing the yellow material was evaporated to dryness. The residue was then dissolved in $1 \%$ sodium bicarbonate solution and submitted to the spectrum determination. This material was found to be DNP-prolyl peptide by its characteristic spectrum ${ }^{13,21)}$ which had only one maximum at $375 \mathrm{~m} \mu$ and minimum at $300 \mathrm{~m} \mu$. The reduction product, prolyl peptide which is considered as Pro-Glu-Ala, confirm the presence of pyroglutamic acid residue at the terminus.

On the basis of these data, it seems most reasonable to conclude that the peptide has a structure of Pyrglu-Glu $\left(\mathrm{NH}_{2}\right)$-Ala, and hence is identical with eisenine.

Synthesis of eisenine To confirm the structure, a tripeptide having the structure of L-Pyrglu-L-Glu $\left(\mathrm{NH}_{2}\right)$-L-Ala was synthesized by essentially the same method described by SHIBA et $a l^{2,8)}$, but $\gamma$-methyl carbobenzoxy-L-glutamate was replaced by $\gamma$-ethyl carbobenzoxy-L-glutamate. The final product was purified by the same procedure as mentioned above. The synthesized eisenine was obtained as long needles: m.p. $222 \sim 223^{\circ} \mathrm{C}$ (decomp, undepressed on admixture with the peptide obtained from the alga). $[\alpha]_{589}^{22}=-48.3^{\circ}(c=1.10$ in water). Anal. Found: $\mathrm{C}, 47.84 ; \mathrm{H}, 6.76 ; \mathrm{N}$, 16.29; eq. wt., 350. Calcd. for $\mathrm{C}_{13} \mathrm{H}_{20} \mathrm{O}_{6} \mathrm{~N}_{4}$ : C, 47.56; H, 6.49; N, 17.08; eq. wt., 328. While color reaction with ninhydrin was negative, biuret reaction was positive. To compare the above preparations further, their infrared spectra were measured by a Perkin-Elmer spectrophotometer. As shown in Fig. 1, the spectra obtained are in 


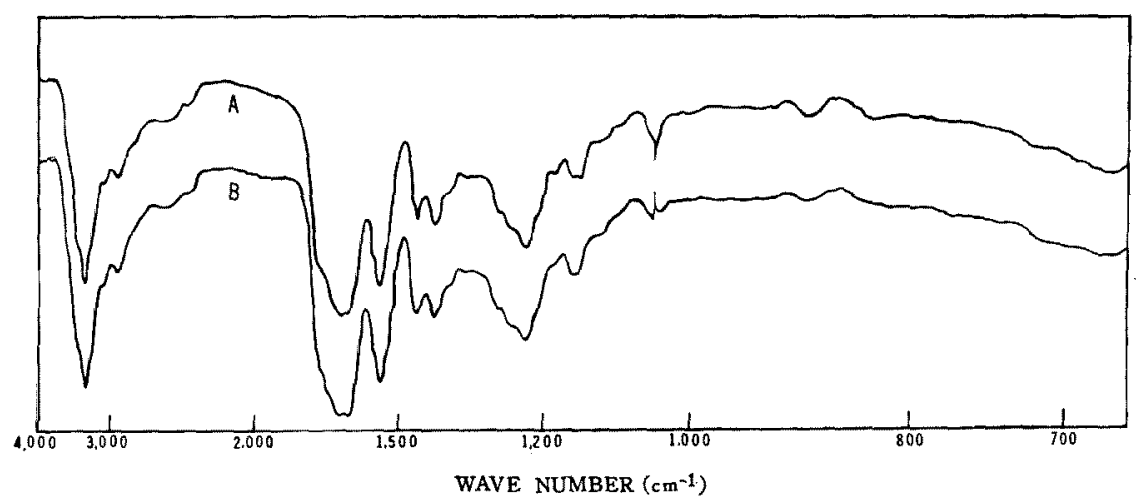

Fig. 1. Infrared absorption spectra of eisenine isolated from Ecklonia cava (A) and the synthesized eisenine (B). ( $\mathrm{KBr}$ pellets).

a good agreement.

\section{Discussion}

From the results of this investigation, it is concluded that the peptide isolated from Ecklonia cava is identical with eisenine from Eisenia bicyclis and has a structure of L-Pyrglu-L-Glu $\left(\mathrm{NH}_{2}\right)$-L-Ala. The possibility of a diketopiperazine structure, glutaminyl-glutamic acid anhydride-alanine was eliminated, while it was advanced by TAzA$\mathrm{WA}^{221}$ on the basis of color reaction and behavior of eisenine towards a few kinds of enzymes.

However, it has been well known that glutaminyl peptides are labile and have a tendency to cyclize to pyroglutamyl peptides ${ }^{23,24}$. A question, therefore, remains still open as to whether the pyroglutamyl peptide, eisenine, may possibly be a peptide formed from the corresponding glutaminyl peptide during the course of isolation.

\section{References}

1) P. HASS and T. G. HILL: Biochem. J., 25, $1472 \sim 1475$ (1931), 27, $1801 \sim 1804$ (1933).

2) P. HAss, T. G. HILL and B. Russell-Wells: Biochem. J., 32, 2129 2133 (1938).

3) P. Hass: Biochem. J., 46, 503 505 (1950).

4) M. Morita: Bull. J. Chem. Soc., 76, 112 114 (1955).

5) C. OgIno: J. Tokyo Univ. Fisheries, 41, 107 152 (1955).

6) T. OHIRA: J. Agr. Chem. Soc. Japan, 15, 370 376 (1939), 16 1 6 (1940), 18, $915 \sim 919$ (1942).

7) T. Shiba and S. Imai: J. Chem. Soc. Japan, 80, 492 497 (1957).

8) T. Kaneko, T. Shiba, S. Wataral, S. Imai, T. Shimada and K. Ueno: Soc. Chim. Ind., 13, $986 \sim 987(1957)$.

9) C. A. Dekrer, D. Stone and J. S. Fruton: J. Biol. Chem., 181, 719 729 (1949).

10) A. Meister: Biochemistry of the Amino Acid, 485 pp., Academic Press Inc., New York (1957).

11) S. MARISUMI: J. Biochem., 46, 63 71 (1959).

12) F. SANGER: Biochem. $J, 39,507 \sim 515$ (1945).

13) H. Fraenkel-Conrat, J. I. HarRis and A. L. LeVY: in "Methods of Biochemical Analysis" 
(D. Glick, ed.) Vol. 2, 359 425, Academic Press Inc., New York (1955).

14) S. Akabori, K. Ohno and K. Narita: Bull. Chem. Soc. Japan, 25, 214 218 (1952).

15) C. I. Niu and H. Fraenkel-Conrat: J. Am. Chem. Soc., 77, 5882 5885 (1955).

16) H. N. Rydon and P. W. G. SMith: Nature, 196, $992 \sim 993$ (1952).

17) M. Nomoto, Y. Narahashi and M. MuraKami: J. Biochem., 48, $906 \sim 918$ (1960).

18) E. Fischer and R. Boemner: Chem. Ber., 44, 1332 1337 (1911).

19) T. Ohira, H. Kido and K. ImaI: J. Agr. Chem. Soc. Japan, 29, 520 522 (1955).

20) K. Ohno and T. SeKI: in "Chemistry of Protein" (S. Akabori and M. Mizushima, ed.) Vol. 4, 209 265, Kyoritsu Shuppan, Tokyo (1956).

21) C. Hashimoto: Bull. Chem. Soc. Japan, 28, 385 389 (1955).

22) Y. TazaWA: Acta. Phytochim., 15, 141 149 (1949).

23) A. C. Chibnall and R. G. Westall: Biochem. J., 26, 122 132 (1932).

24) J. Melville: Biochem. J., 29, 179 186 (1936). 